\author{
Maciej Kruszyna \\ dr hab. inż. prof. PWr \\ Politechnika Wrocławska, \\ Wydział Budownictwa Lądowego i Wodnego \\ Katedra Dróg, Mostów, Kolei i Lotnisk \\ maciej.kruszyna@pwr.edu.pl
}

DOI: 10.35117/A_ENG_21_09_10_11_09

\title{
Integration of Polish airports with local rail transport
}

\begin{abstract}
Out of 15 Polish airports serving regular passenger connections, only 5 are integrated with local passenger rail transport, and this integration has a differ scale, which translates into the efficiency of intermodal connections and their popularity among travelers. There are also numerous plans to build or modernize railway lines and, incidentally, also tram lines to improve airport accessibility. Author of this paper discusses the existing and planned (as well as potential) solutions, focusing on local (agglomeration) transport. The issue of integration of CPK (Centralny Port Komunikacyjny = Central Transportation Hub) with the long-distance rail network is only outlined as a topic with different specificity and as such deserves a separate publication.
\end{abstract}

Keywords: Airport; Local rail transport; Integration

\section{Introduction}

Providing access to the airport by rail (and in particular by rail) is an important issue in terms of balancing the division of transport tasks and shaping ecological mobility. This becomes important at large and large airports, but also worth considering for smaller airports. In the world, we can observe an increasing role of commuting to airports without the use of a car and new investments in rail transport infrastructure integrated with airport terminals are appearing in many locations. Two approaches can be distinguished (not necessarily competing with each other): including the airport in the local (agglomeration) rail network; inclusion of the airport in the network of long-distance rail transport. Both of these forms are present, for example, at the Frankfurt Main airport (among the top ten airports in the world), where there are separate stops for both types of connections, while the newer one concerns long-distance transport.

There are small and medium-sized airports in Poland (from the point of view of European transport). Nevertheless, it is reasonable to implement rail connections to all airports that have more or less regular passenger transport, also due to the potential intensification of transport, which in turn may be the result of improved airport accessibility after the commencement of access by rail. The publication [3] cites a map of the locations of important airports in Poland against the background of local rail networks (Figure 1). 


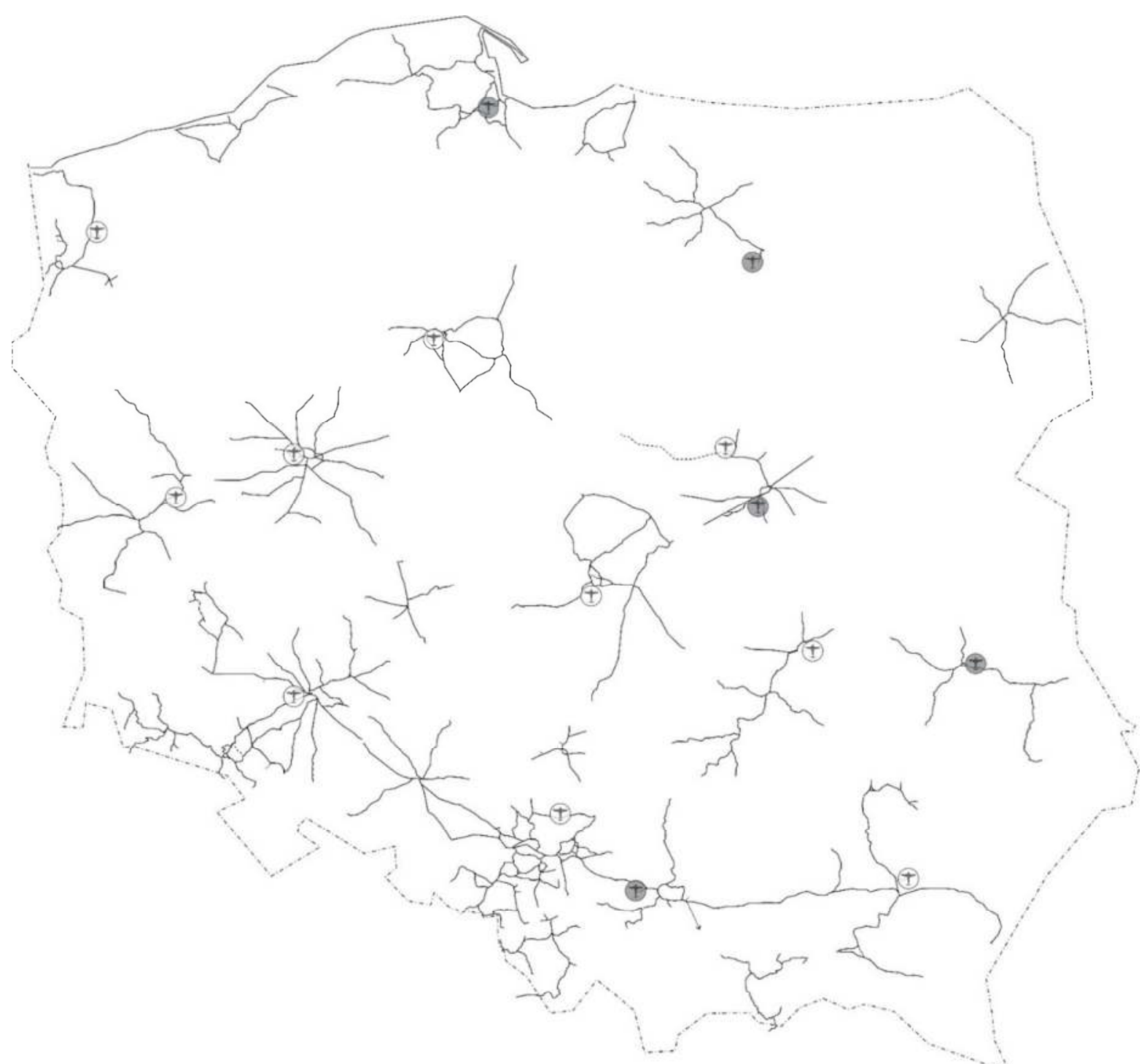

1. Location map of important airports in Poland together with the layouts of local rail networks [3]

15 airports were indicated, distinguishing those to which rail transport was provided (Gdańsk, Olsztyn - Szymany, Warsaw Okęcie, Lublin and Kraków) and others (Szczecin Goleniów, Bydgoszcz, Poznań, Zielona Góra - Babimost, Wrocław, Łódź, Modlin, Katowice - Pyrzowice, Radom and Rzeszów). The article presents selected solutions, whether functioning or planned or implemented. The connections of a local nature were limited, without taking into account the issue of CTH.

\section{Example 1: Gdańsk, perhaps a perfect model?}

A relatively new element of the agglomeration railway system in the Tri-City is the Pomeranian Metropolitan Railway, PKM. The PKM line was built in 2013-2015 by the consortium of Budimex and Ferrovial Agroman companies at the request of the company Pomorska Kolej Metropolitalna, which is the manager of this line. Passenger train traffic began on September 1, 2015, and their operator is PKP Szybka Kolej Miejska in the Tri-City. The aim of the PKM program was to increase the level of social and economic cohesion of the Pomeranian Voivodeship by implementing the KR system integrated with the public transport system of the Tri-City Metropolis. The program covered mainly the Tri-City agglomeration area and the following poviats: Bytów, Kościerzyna, Kartuski. The first stage of the 
investment meant the reconstruction of the network by revitalizing the Kokoszkowska Railway, closed since 1945, and the construction of a section connecting the southern districts of the City of Gdańsk with the airport in Rębiechowo and the Gdynia - Kościerzyna railway line. The planned solution opened the Metropolis to Kashubia, enabling the access of residents and tourists to Kartuzy, Kościerzyna, or Bytów, and facilitating and significantly accelerating the journey from the depths of the voivodeship to the Tri-City.

The PKM route (Figure 2) consists of several parts: a section of the Gdańsk Wrzeszcz Kokoszki railway line existing until 1945 (up to $9.8 \mathrm{~km}$ of this line), a section of the railway line built from scratch to the place of its inclusion in line 201 (Nowa Wieś Wielka Kościerzyna) - Gdynia Port (up to $18.3 \mathrm{~km}$ ) with a slip road from the planned technical station (Barniewicka) towards Kościerzyna, approximately $1.35 \mathrm{~km}$ long. The project also included the construction of 8 stops. bus, Park, and Ride). The construction of access roads, parking lots, and new bus and tram stops is carried out by the city of Gdańsk, which thus joined the project. Such an implementation of the project, where the voivodeship (as the main investor) takes the burden of building a railway line with all stops, and the local government builds access roads and interchange junctions at individual stops has proved successful in the implementation of the project and can be a model for other systems. The investment included the airport in the railway network not through a blindsiding, but a stop on the crossing railway line. It is a very effective and unique solution on a Polish scale.

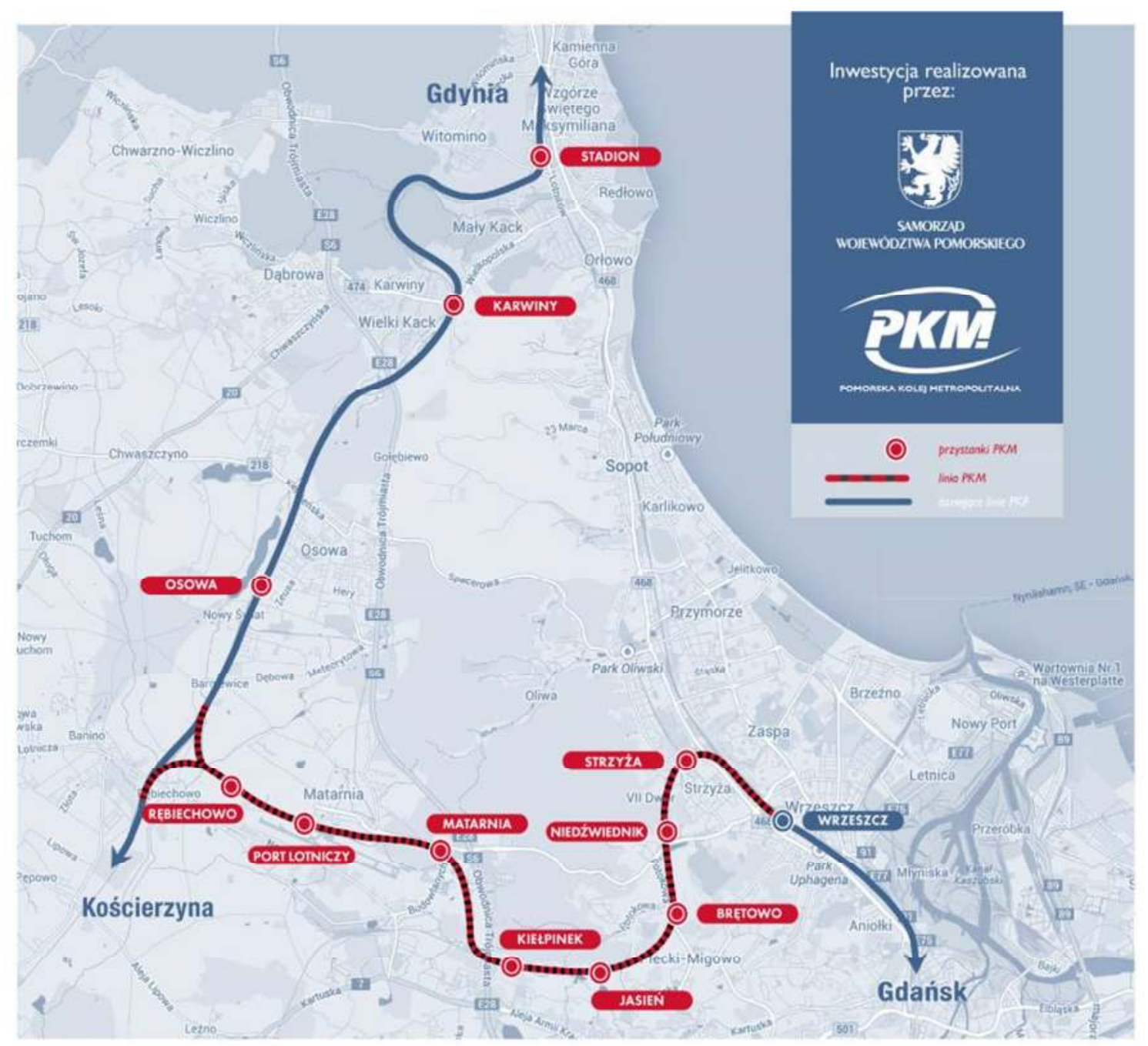

2. The PKM line supporting, among others airport in Gdańsk [4] 


\section{Example 2: Krakow, end stop problem}

The local carrier Koleje Małopolskie (KMŁ) operates in the Małopolskie Voivodeship. KMŁ is a railway carrier established by the local government of the Małopolskie Voivodeship by a resolution of December 2, 2013 [7]. The company was established to provide services of general interest in the field of public transport by ensuring the effective organization and operation of passenger rail traffic in the Małopolskie Voivodeship. In recent years, the company has been operating on various routes known as the Fast Agglomeration Railway (SKA), although some of these lines are regional railways. The route: Wieliczka Rynek Kraków Główny - Kraków Airport (Balice) - Figure 3 is the most urban in character, although stops are being densified here and the line infrastructure is being expanded.

Ultimately, the KA network will be created with a significant share of tracks separated from long-distance traffic and a high density of stops. This will allow for the improvement of connections within the Krakow Functional Area (KrOF). KrOF was identified in the ROP project of the Małopolskie Voivodeship as a delimitation of intervention in the ITI formula [5]. Interventions under the ITI will be implemented in the area with intense functional connections between Krakow and the surrounding municipalities: Biskupice, Czernichów, Igołomia Wawrzeńczyce, Kocmyrzów Luborzyca, Liszki, Michałowice, Mogilany, Niepołomice, Skawina, Świątniki Górne, Wieliczka, Wielka Wieś, Zabierzów, Zielonki. It is an area separated from the sub-region: Krakow Metropolitan Area - Krakow Metropolis. The total area of the ITI area is $1,275 \mathrm{~km}^{2}$, of which $326.8 \mathrm{~km}^{2}$ is occupied by the city of Krakow, and $948.2 \mathrm{~km}^{2}$ by the suburban area. The population of $\mathrm{KrOF}$ at the end of 2013 was 1.03 million, including 275 thousand. people lived in the suburban area [3].

The Krakow example features the routing of a railway line to the airport as an additional and final stop in the network. Thus, only (or almost) only passengers interested in the airport will use the section of the network connected to the airport. A similar configuration of access to airports is used in Warsaw (Okęcie), Lublin and Szymany.

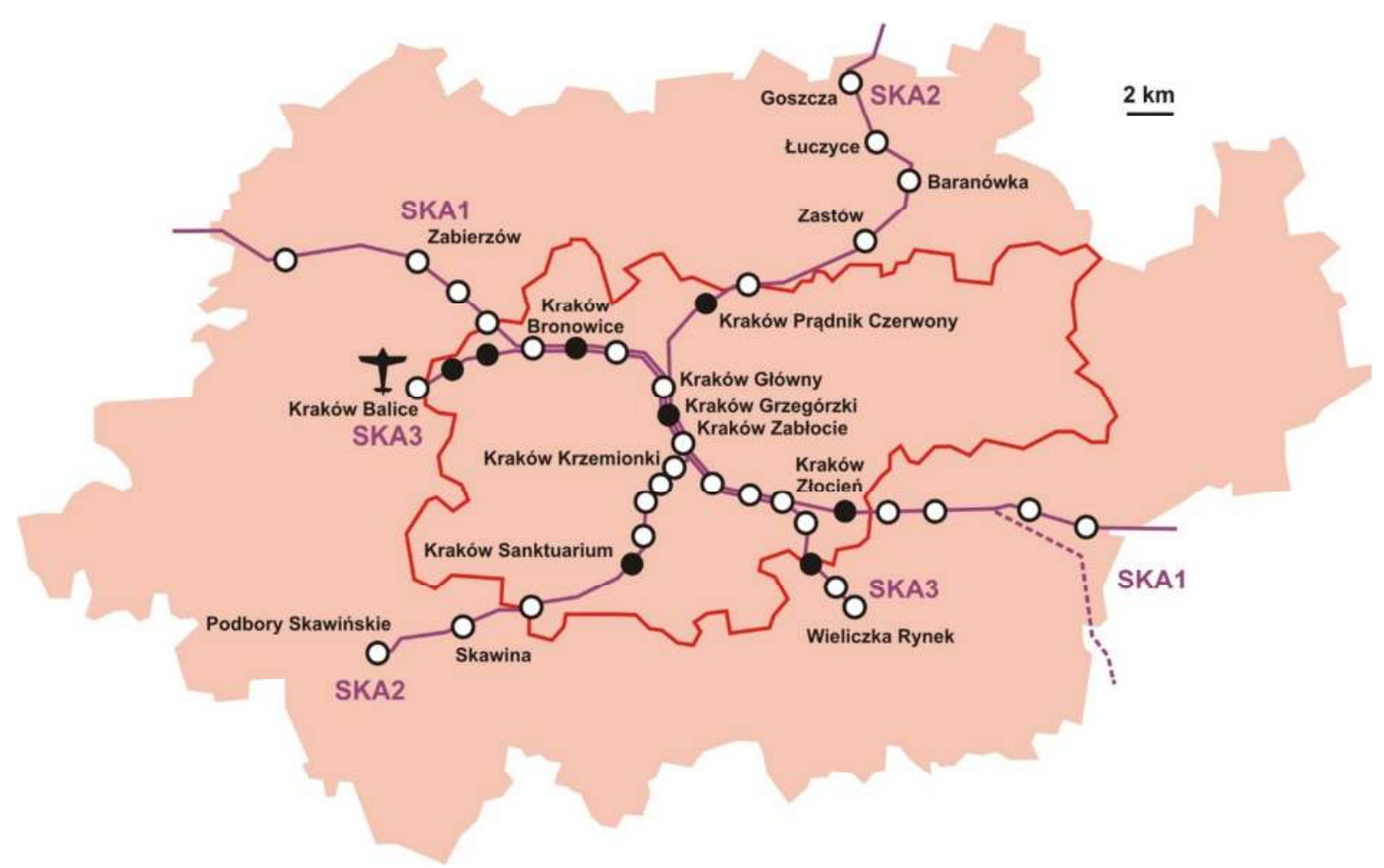

3. SKA network in the Krakow Agglomeration [3] 


\section{Example 3: Wrocław, problem with routing of a railway line}

Within the agglomeration mainline system, the issue of connection to an airport is being considered [2]. On the one hand, the public transport system must enable the inhabitants of the entire agglomeration (and even a larger area of influence) to reach the airport effectively. On the other hand, airport-related travel is not a daily activity of the agglomeration's inhabitants (except for commuting at the airport). The following may be decisive for the decision to build a new connection to the airport: the volume of air traffic and the local configuration of transport networks. In some cases, it may turn out that the most sensible option is to create a special line connecting the airport with the agglomeration center (for example, with the main node - the railway station). In this case, it is possible to introduce an additional, specific means of transport (including BRT, magnetic railway). On the other hand, it may be attractive to integrate the airport connection into the system of "normal" main lines (including railways). This makes it possible to travel to the airport without changing from selected areas of the agglomeration. However, such an option must result from the "favorable" route of the existing routes. Carrying out too costly investments to integrate the airport into the infrastructure seems to be ineffective.

Such a problem is present in Wrocław, where the airport is located between two important railway lines (274 to Wałbrzych and further, 275 to Legnica and further), but at a fairly large distance from them (Figure 4).

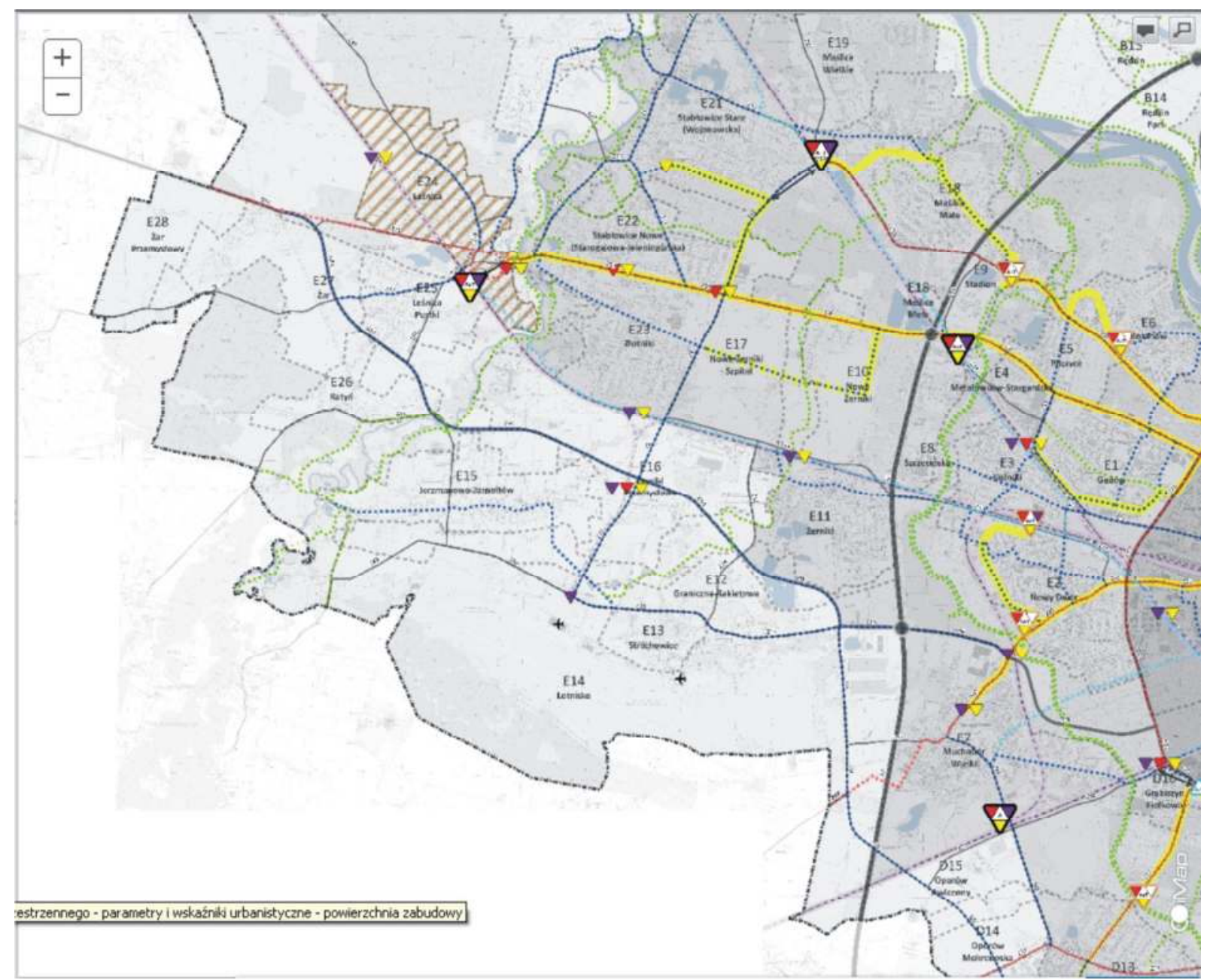

4. An excerpt from the Study of Land Use and Development Directions in Wrocław presenting, inter alia, potential train connection to the airport [6] 
On the one hand, it creates potential opportunities for creating a railway connection to the airport not only from Wrocław but also from other towns in the region. On the other hand, it makes planning decisions difficult. In fact, in recent years, numerous concepts have been formulated to connect to one or the other line - with the final stop "airport". The concept in Figure 4 shows the connection to line 275. There is also a concept of connecting the two lines with the "flight" through the airport - very attractive in terms of functionality, but requiring a train tunnel under the landing area, which is technically not impossible but is expensive. Due to the above-mentioned conditions, the task of connecting the railway to the Wrocław airport is still a concept. A similar situation (formulation of the concept) also applies to other airports in Poland, including: Poznań, Szczecin (Goleniów), Rzeszów, Bydgoszcz, Modlin and Babimost. Discussion of these concepts can be found, among others In [3].

\section{Example 4: Katowice - Pyrzowice, new implementation}

An interesting situation concerns the Upper Silesian-Zagłębie agglomeration and the airport in Pyrzowice operating on its territory. The airport is located between the lines with passenger connections (stations: Tarnowskie Góry, Zawiercie), and in its vicinity, there is line 182, currently revitalized for passenger transport, including airport service.

As a result of the investment [1], the journey by rail from Zawiercie will take 23 minutes, and from Tarnowskie Góry less than 20 minutes. Journeys from Katowice and Częstochowa will take about 1 hour. In addition to the Pyrzowice Airport station, there will be new stops: Miasteczko Śląskie Centrum, Mierzęcice, and Zawiercie Kądzielów. On the other hand, at Tarnowskie Góry, Siewierz, and Poręba stations, platforms will be modernized, and Zawiercie will be enriched with a new platform (Figure 5).

\section{Pociągiem na lotnisko w Pyrzowicach}

Szybko, sprawnie i komfortowo pociągiem z Tarnowskich Gór i Zawiercia do portu lotniczego Katowice Airport w Pyrzowicach. PKP Polskie Linie Kolejowe S.A. rozpoczęły realizację inwestycji ważnej dla ruchu pasażerskiego i towarowego w województwie śląskim. Powstaną nowa stacja kolejowa, nowe przystanki, odbudowany zostanie także 30-kilometrowy odcinek nieczynnego toru na trasie Tarnowskie Góry - Siewierz.

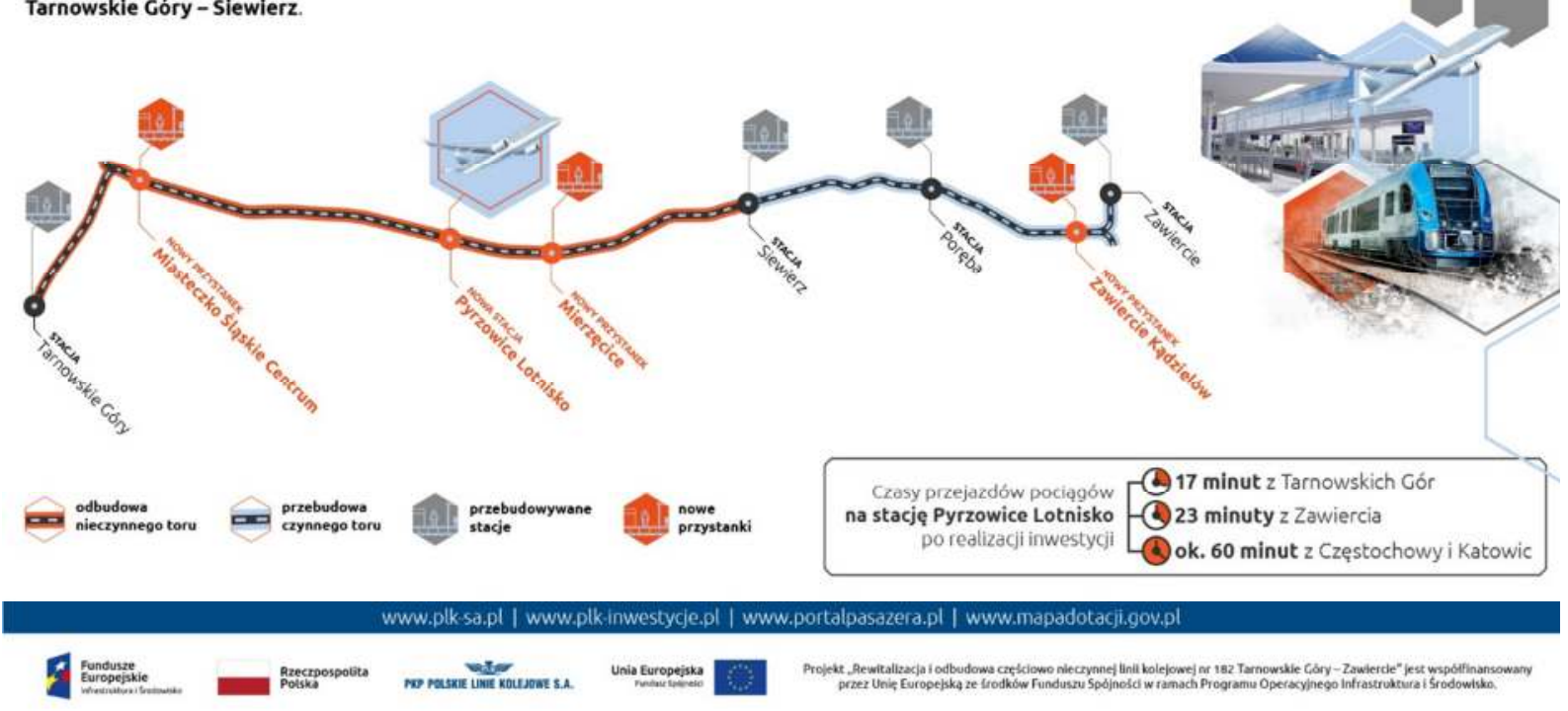

5. Information on the investment regarding the revitalization of railway line No. 182 [1]

The implementation of the project "Revitalization and reconstruction of the partially disused railway line No. 182 Tarnowskie Góry - Zawiercie" will cost PLN 660 million net, with the majority of this amount being covered by EU funding from the Infrastructure and Environment Operational Program in the amount exceeding PLN 500 million. The investment is to be completed in the second quarter of 2023. 
The connection to the Pyrzowice airport will not create the fastest connection with Katowice, but from the perspective of the entire agglomeration or the Silesian Voivodeship, and due to the inclusion in the regional system of rail connections, it will certainly be an attractive element of it. It remains to be wished success to other airports in the implementation of plans and the concept of including them in the rail transport network

\section{Summary}

A railway connection has been established to several airports in Poland. In other locations, such investments are planned or are already underway. Certainly, such solutions are beneficial by creating alternative possibilities of reaching airports. In the light of the principles of sustainable mobility (and development), it is worthwhile to have the highest possible share of non-car journeys, including those related to airports. The presented examples show that the most effective route of the line to the airport consists in including it in the regional transport system. Running the railway line only to the airport limits the availability and the number of passengers. However, it is not always possible (economically effective) to plan the route so that the "airport" stop is not the final stop. The obstacle may be the conditions of spatial development, routing barriers, existing buildings, etc. However, if possible, a crossing system with the launch of routes running through the airport area, and not only serving air traffic, is recommended.

\section{Source materials}

[1] https://inzynieria.com/drogi/wiadomosci/61006, wiecej-prac-na-budowie-liniikolejowej-do-katowickiego-lotniska-film,inwestycja-za-660-mln-zl@inzynieria.com

[2] Kruszyna M. Klucz do planowania transportu publicznego w aglomeracji "30/6". Studia nad Rozwojem Dolnego Śląska. 2014, nr 3, s. 9-63.

[3] Kruszyna M. „Koleje miejskie i regionalne w Polsce”, Monografia, Łódź: Księży Młyn Dom Wydawniczy, 2018.

[4] Materiały PKM

[5] Strategia Zintegrowanych Inwestycji Terytorialnych dla Krakowskiego Obszaru Funkcjonalnego http://metropoliakrakowska.pl/zit/strategia

[6] Studium uwarunkowań i kierunków zagospodarowania przestrzennego Wrocławia uchwalone 11 stycznia $2018 \mathrm{r}$.

[7] www.malopolskiekoleje.pl 